\title{
A huge benign fibrous histiocytoma arising from the renal capsule: report of a case
}

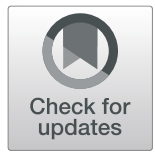

\author{
Chao Sun ${ }^{1 *} \mathbb{D}$, Shengli Wang ${ }^{1}$, Bo Li ${ }^{1}$ and Xueting Sun ${ }^{2}$
}

\begin{abstract}
Background: Neoplasms originating in the renal capsule are very rare. Benign fibrous histiocytoma(BFH) most commonly occurs in the dermis and subcutis, few cases of this tumor appear in the renal capsule. In particular, BFH larger than $20 \mathrm{~cm}$ are scarce. Here we report a rare huge one measuring $23 \times 13 \times 7 \mathrm{~cm}$.

Case presentation: We report a 64-year-old man who presented with a few-months history of dull pain in the right groin. The tumor had its point of origin in the renal capsule which is a rare condition. Histologically, the tumor was composed of intersecting fascicles of fibroblastic cells forming a "storiform" pattern. Immunohistochemical studies were also performed, ultimately leading to the diagnosis of BFH. The patient was treated with radical nephrectomy. No recurrence was detected 4 months after surgery.

Conclusions: BFH arising from the renal capsule was very rare. In particular, the case of more than twenty centimeters is extremely rare. The clinical presentation of renal BFH might be only a mass. However, differential diagnosis from renal cell carcinoma proved to be impossible before surgical intervention. It is difficult to diagnose only by means of histopathology, but the immunohistochemical method can provide a clear and definite diagnosis.
\end{abstract}

Keywords: Benign fibrous histiocytoma, Renal capsule, Renal neoplasms

\section{Background}

Benign fibrous histiocytoma(BFH) most commonly occurs in the dermis and subcutis, deeply-situated counterparts originating in bone [1] and deeper soft tissue have been described but less common than cutaneous ones [2]. This tumor rarely occurs in the parenchyma organs [3, 4], and Shoji K. et al. first reported a case of $\mathrm{BFH}$ originating in the renal capsule in 1992 [5], measuring $6 \times 4.5 \times 6 \mathrm{~cm}$. In this paper we report a huge $\mathrm{BFH}$ measuring $23 \times 13 \times 7 \mathrm{~cm}$, and the clinical picture and pathological findings are described.

\section{Case presentation}

A 64-year-old man was hospitalized for a few-months history of dull pain in the right groin. Physical examination revealed a palpable mass in the right flank with a mild right flank tenderness. His previous history was uneventful. The results of laboratory examination were unremarkable. Screening ultrasound examination revealed

\footnotetext{
* Correspondence: 414411899@qq.com

'Department of Urology, The third the People's Hospital of Bengbu, 38\#

Shengli Road, Bengbu, Anhui Province, China

Full list of author information is available at the end of the article
}

a hypoechoic tumor with inhomogeneous interior echoes, $23 \times 13 \times 7 \mathrm{~cm}$ in size. Computerized tomography $(\mathrm{CT})$ confirmed the presence of a solid tumor of the right kidney about $20 \mathrm{~cm}$ in diameter (Fig. 1a, arrow). Renal arteriography demonstrated a hypovascular tumor and compressed deformity of pelvis of the right kidney (Fig. 1b, arrow). The left kidney was normal. Suspecting a renal carcinoma the patient underwent a right radical nephrectomy in February 2018. He had an uneventful post-operative recovery, and is currently well without any sign of recurrence.

Grossly, the tumor was solitary and sharply defined, measuring $23 \times 13 \times 7 \mathrm{~cm}$ (Fig. 2a). The cut surface was solid, elastic hard, and white yellowish without hemorrhage or necrosis (Fig. 2b). The pyelocaliceal system and the renal vessels were free of tumor involvement. Microscopic examination of the tumor disclosed intersecting fascicles of fibroblastic cells forming a loose crisscross or "storiform" pattern (Fig. 3a). And we observed that there was a clear boundary between the tumor and the kidney tissue under the microscope, which kept in line with the CT representation (Fig. 3b). The tumor was basically histiocytic, presenting a great 


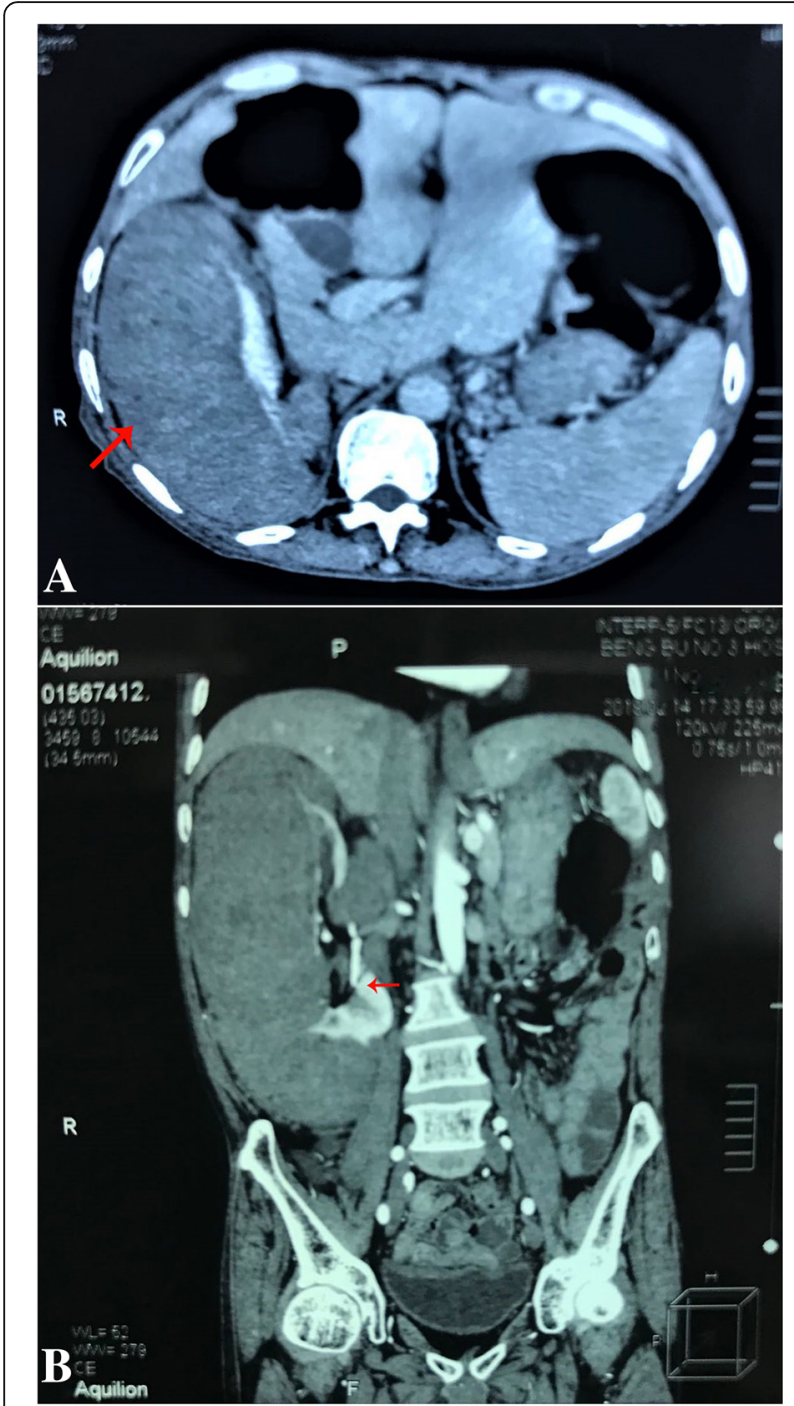

Fig. 1 a CT scan demonstrates a large solid mass of the right kidney about $20 \mathrm{~cm}$ in diameter (arrow); b Renal arteriography demonstrated a hypovascular tumor and compressed deformity of pelvis of the right kidney (arrow)

deal of collagenic fibers, upon the presence of foam cells. The multinucleated giant cells and undifferentiated mesenchymal cells were very low. In addition, the cells were well differentiated, and the nuclei were not deep stained with very low heteromorphism.

Immunohistochemical studies showed that the tumor cells were strongly and positive for CD34, vimentin and CD99, the proliferation index of $\mathrm{Ki}-67$ was $1 \%$, but were negative for the smooth muscle actin (SMA), the desmin, SOX10, Bcl-2, CK7, the melanogenesis marker (HMB45), MelanA and the S-100 protein.

\section{Discussion and conclusions}

Neoplasms originating in the renal capsule are very rare. Among fibrohistiocytic tumors, BFH [5] and malignant
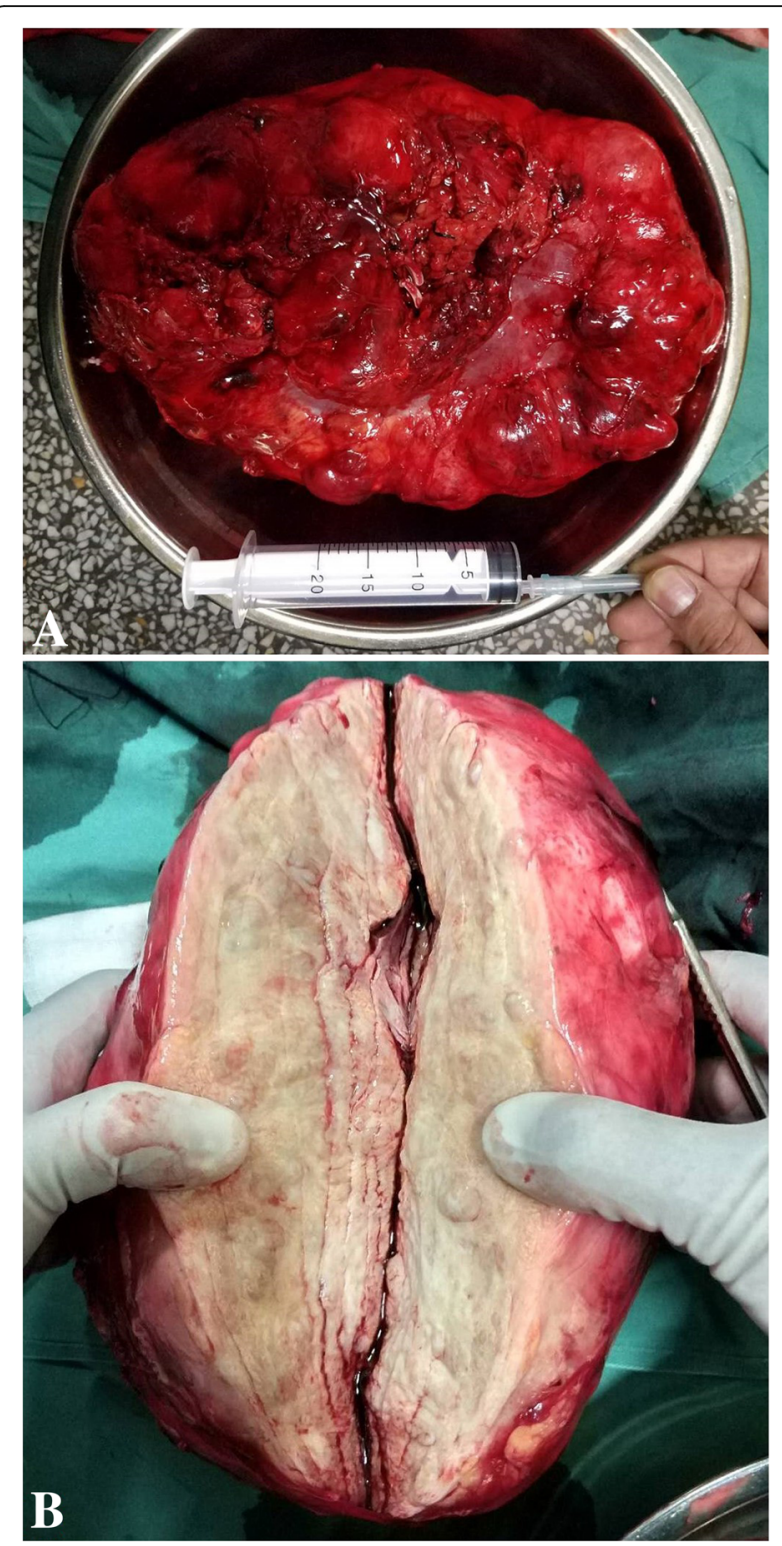

Fig. 2 a The tumor was grossly solitary and sharply defined, measuring $23 \times 13 \times 7 \mathrm{~cm}$; b The cut surface was solid, elastic hard, and white yellowish without hemorrhage or necrosis

fibrous histiocytoma(MFH) $[6,7]$ have been described in the literature. Shoji K. et al. first reported a case of BFH originating in the renal capsule in 1992 [5], measuring $6 \times 4.5 \times 6 \mathrm{~cm}$. Here we report a huge one measuring $23 \times 13 \times 7 \mathrm{~cm}$.

BFH most common arise from the dermis. There have been a few cases reported that this tumor appeared in parenchymal organs, such as the kidney [4] lung [3], and orbit $[8,9]$. The $\mathrm{BFH}$ we describe had its point of origin in the renal capsule outside the kidney. The tumor was well circumscribed by thick connective tissue and had no infiltrating features. Expanding from this place, the 


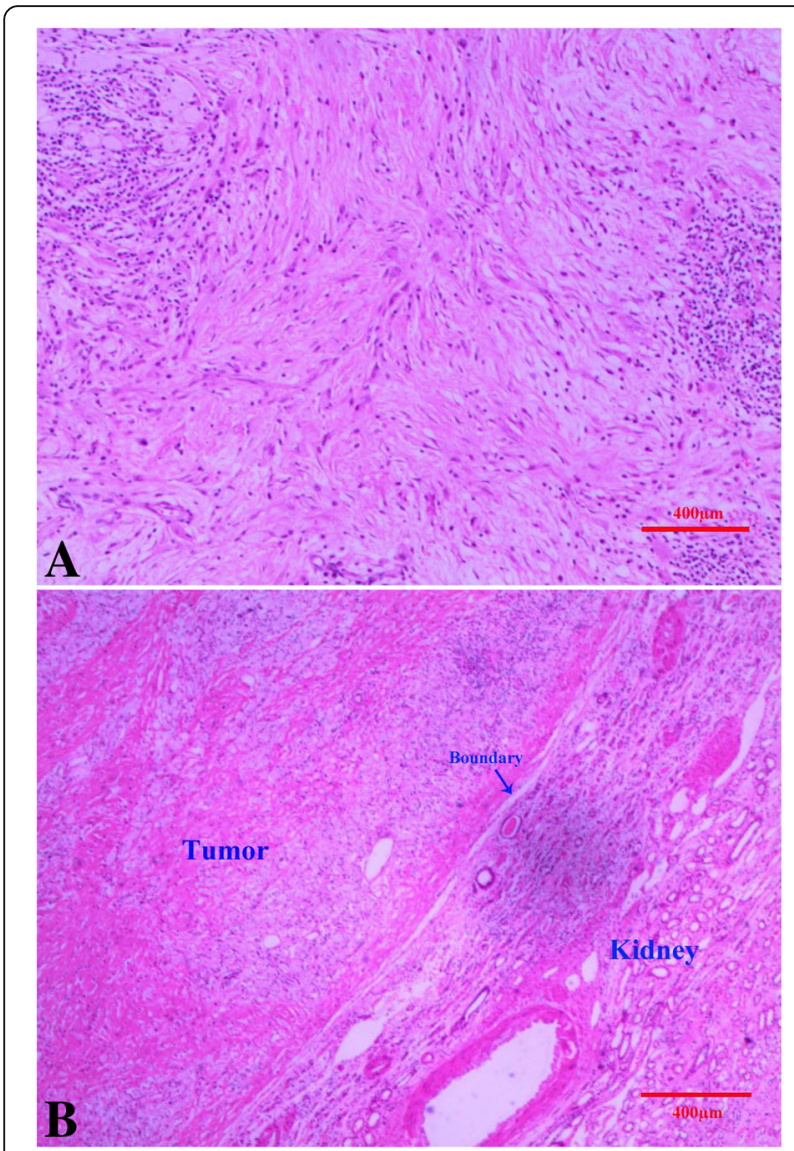

Fig. 3 a: The tumor disclosed intersecting fascicles of fibroblastic cells forming a "storiform" pattern; $\mathbf{b}$ : There was a clear boundary between the tumor and the kidney tissue under the microscope. HE. $\times 100$

tumor displaced the kidney without involving the renal parenchyma. The results we reported were consistent with Shoji K. et al. reported [5]. Otherwise, in the first reported case of $\mathrm{BFH}$ in the kidney which was not from the renal capsule [8], the tumor occupied the middle pole of the kidney and compressed the lower and middle portion of the renal pelvis.

BFH included fibroxanthoma, atypical fibroxanthoma, dermatofibroma and sclerosing hemangioma. All of these tumors showed mainly histiocytic properties, but they vary depending on the amount of collagen fibers, or on the existence of foam cells, capillaries, multinucleated giant cells and hemosiderin [10]. In our case tumor cells showed mainly fibroblastic properties consisting of a storiform arrangement. Furthermore, the tumor presented a great deal of collagenic fibers, upon the presence of foam cells. The multinucleated giant cells and undifferentiated mesenchymal cells were very low. The cells were well differentiated and the nuclei were not deep stained with very low heteromorphism.
$\mathrm{MFH}$ is the most frequently subtype of soft-tissue sarcoma in late adulthood in both sexes and left renal predilection [11, 12]. Approximately one third of MFH occurs in the extremities [13]. Retroperitoneum or kidney origin accounts for $12-14 \%$ of all cases [14]. There are few reported cases of MFH definitely arising from the renal capsule $[6,7,15,16]$. The histology characters of MFH were groups of histiocytes and pleomorphic giant cells with large nuclei and moderate mitotic activity. And the prognosis of MFH is different from BFH. Despite extensive surgical excision, MFH shows a very poor prognosis for local recurrence or distant metastasis. Sixty percent of patients died of the disease within 1 year of surgery $[12,17]$.

The majority diagnostic imaging of $\mathrm{BFH}$ and $\mathrm{MFH}$ included ultrasound and CT. Ultrasound in most of the cases showed a well-defined mass with a rather complex internal pattern. In our case this method showed a spherical well defined echogenic mass. CT showed a solid mass with or without necrotic areas. However, it cannot be differentiated radiologically from renal cell carcinoma. Thus, treatment selection was no more than a radical nephrectomy because of suspicion of renal cell carcinoma. We performed a transperitoneal nephrectomy, and the patient is currently well without any sign of recurrence.

It is difficult to diagnose by histopathological methods, whereas immunohistochemistry can provide a relatively correct diagnosis [18]. In this case, immunohistochemical staining of various elements was of assistance. Some researchers recommend the use of electron microscopy [19], but other researchers believe that the effect of electron microscopy is limited because it does not show specific features of epithelial and histiocytic features [20].

$\mathrm{BFH}$ arising from the renal capsule was very rare. In particular, the case of more than twenty centimeters is extremely rare. The clinical presentation of renal $\mathrm{BFH}$ might be only a mass. However, differential diagnosis from renal cell carcinoma proved to be impossible before surgical intervention. It is difficult to diagnose only by means of histopathology, but the immunohistochemical method can provide a clear and definite diagnosis.

\section{Abbreviations}

BFH: Benign fibrous histiocytoma; CT: Computerized tomography MFH: Malignant fibrous histiocytoma; SMA: Smooth muscle actin

\section{Acknowledgements}

Not applicable.

\section{Funding}

Not applicable.

Availability of data and materials

All data related to this case report are within the manuscript. 


\section{Authors' contributions}

SC collected the data, wrote and revised critically the manuscript. WSL and LB contributed to participating in the operation process as first aid and second aid respectively and collecting case data in this manuscript. SXT contributed to the image interpretation and intellectual content in the manuscript. All authors read the final manuscript and approved it.

\section{Ethics approval and consent to participate}

Not applicable.

\section{Consent for publication}

Written consent was obtained from the patient for publication of the case report and all images in it.

\section{Competing interests}

The authors declare that they have no competing interests.

\section{Publisher's Note}

Springer Nature remains neutral with regard to jurisdictional claims in published maps and institutional affiliations.

\section{Author details}

'Department of Urology, The third the People's Hospital of Bengbu, 38\# Shengli Road, Bengbu, Anhui Province, China. ${ }^{2}$ Department of Nursing, The third the People's Hospital of Bengbu, 38\# Shengli Road, Bengbu, Anhui Province, China.

Received: 6 September 2018 Accepted: 18 February 2019

Published online: 21 February 2019

\section{References}

1. Li Z, Zhu N, Su J, Li J, Deng C, Zhao L, Pang Q. Benign fibrous histiocytoma of the frontal bone. J Craniofac Surg. 2016;27(3):e302-4

2. Fletcher CD. Benign fibrous histiocytoma of subcutaneous and deep soft tissue: a clinicopathologic analysis of 21 cases. Am J Surg Pathol. 1990;14(9):801-9.

3. Numata A, Masuda T, Okayasu T, Hashimoto M, Tanabe T. A case of benign fibrous histiocytoma of the lung in a child. Nihon Kyobu Geka Gakkai Zasshi. 1989;37(2):350-4

4. Sakakibara N, Seki T, Maru A, Koyanagi T. Benign fibrous histiocytoma of the kidney. J Urol. 1989;142(6):1558-9.

5. Kobayashi S, Yamadori I, Ohmori M, Akaeda T. Benign fibrous histiocytoma of the renal capsule. Acta Pathol Jpn. 1992:42(3):217-20.

6. Bairwa S, Sangwaiya A, Ansari M, Jindal A, Singla S, Yadav A. Malignant fibrous histiocytoma arising from renal capsule: an extremely rare entity. Indian J Pathol Microbiol. 2017;60(3):402-4.

7. Matsushita M, Okada T, Kawamura N, Ujike T, Nin M, Tsujihata M. A case report of malignant fibrous histiocytoma arising from the renal capsule. Hinyokika Kiyo. 2013;59(11):733-6.

8. Furusato E, Valenzuela IA, Fanburg-Smith JC, Auerbach A, Furusato B, Cameron JD, Rushing EJ. Orbital solitary fibrous tumor: encompassing terminology for hemangiopericytoma, giant cell angiofibroma, and fibrous histiocytoma of the orbit: reappraisal of 41 cases. Hum Pathol. 2011:42(1):120-8.

9. Boehlke CS, Frueh BR, Flint A, Elner VM. Malignant fibrous histiocytoma of the lateral conjunctiva and anterior orbit. Ophthalmic Plast Reconstr Surg. 2007;23(4):338-40.

10. Varma P. Walia S, Manglawat R. Benign fibrous histiocytoma. Indian J Ophthalmol. 2014;62(4):464-7.

11. Gogus C, Gokce MI, Suer E, Tulunay O, Safak M. Primary malignant fibrous histiocytoma of the kidney: report of a case and literature review. Turk J Urol. 2013;39(3):194-7.

12. Tarjan M, Cserni G, Szabo Z. Malignant fibrous histiocytoma of the kidney. Scand J Urol Nephrol. 2001;35(6):518-20.

13. Vasileios KA, Eward WC, Brigman BE. Surgical treatment and prognosis in patients with high-grade soft tissue malignant fibrous histiocytoma of the extremities. Arch Orthop Trauma Surg. 2012;132(7):955-61.

14. Usher SM, Beckley S, Merrin CE. Malignant fibrous histiocytoma of the retroperitoneum and genitourinary tract: a clinicopathological correlation and review of the literature. J Urol. 1979;122(1):105-9.
15. Kitajima K, Kaji Y, Morita M, Okuda Y, Sugimura K. Malignant fibrous histiocytoma arising from the renal capsule. Magn Reson Med Sci. 2003;2(4):199-202

16. Kanno T, Kamoto T, Terai A, Kakehi Y, Terachi T, Ogawa O. A case of malignant fibrous histiocytoma arising from the renal capsule. Hinyokika Kiyo. 2001;47(2):95-8.

17. Froehner M, Manseck A, Haase M, Hakenberg OW, Wirth MP. Locally recurrent malignant fibrous histiocytoma: a rare and aggressive genitourinary malignancy. Urol Int. 1999;62(3):164-70.

18. Ptochos A, Karydas G, losifidis N, Tyrothoulakis E, Papazafiriou G, KehagiaKoutoufari T. Primary renal malignant fibrous histiocytoma. A case report and review of the literature. Urol Int. 1999;63(4):261-4.

19. Argenyi ZB, Van Rybroek JJ, Kemp JD, Soper RT. Congenital angiomatoid malignant fibrous histiocytoma. A light-microscopic, immunopathologic, and electron-microscopic study. Am J Dermatopathol. 1988;10(1):59-67.

20. Pearson JM, Banerjee SS, Haboubi NY. Two cases of pseudosarcomatous invasive transitional cell carcinoma of the urinary bladder mimicking malignant fibrous histiocytoma. Histopathology. 1989;15(1):93-6.

\section{Ready to submit your research? Choose BMC and benefit from:}

- fast, convenient online submission

- thorough peer review by experienced researchers in your field

- rapid publication on acceptance

- support for research data, including large and complex data types

- gold Open Access which fosters wider collaboration and increased citations

- maximum visibility for your research: over $100 \mathrm{M}$ website views per year

At $\mathrm{BMC}$, research is always in progress.

Learn more biomedcentral.com/submission 